\title{
THE EFFECT OF DIRECTED READING THINKING ACTIVITY (DRTA) LEARNING STRATEGY AND READING INTEREST FOR READING COMPREHENSION ABILITY
}

\author{
Arini Itsna Annida, St. Y. Slamet, Retno Winarni
}

Universitas Sebelas Maret

arini.annida@gmail.com

Article History

accepted 09/07/2018

approved 01/08/2018

published 17/09/2018

\section{Keywords}

reading comprehension ability, reading interest, Directed Reading Thinking Activity, Know-Want to Know-Learned

\begin{abstract}
This research is intended to find the different of reading comprehension ability of student that teached by teaching Directed Reading Thinking Activity (DRTA) learning strategy within Know-Want to Know-Learned (KWL) learning strategy, the different of reading comprehension ability of student that have the high reading interest and low reading interest, and the interaction between learning strategy and studied reading interest on the reading comprehension ability. This study was a quasi experimental research methode design by $2 \times 2$ factorial design. Population of the research are all student at fifth grade of elementary school in Laweyan district Surakarta in the academic year of 2017/2018. Samples were taken by cluster random sampling technique. The selected sample are Pajang 1 elementary school and Karangasem 1 elementary School. The data collecting uses test and non test technique. This research used two ways anava data analysis technique and used Scheffe method as a further testing after two ways anova with 5\% of significance level. The result of research shows that a different of reading comprehension ability of student that teached by Directed Reading Thinking (DRTA) learning strategy within Know-Want to Know-Learned (KWL) learning strategy, there was a different of reading comprehension ability of student that have the high reading interest and low reading interest, and there was an interaction between learning strategy and reading interest on the reading comprehension ability.
\end{abstract}

Social, Humanities, and Education Studies (SHEs): Conference Series https://jurnal.uns.ac.id/shes

p-ISSN 2620-9284 e-ISSN 2620-9292 


\section{PENDAHULUAN}

Membaca merupakan salah satu aspek keterampilan berbahasa yang harus dimiliki oleh setiap individu dalam kehidupan bermasyarakat. Kemampuan membaca menjadi hal yang penting, sebab melalui membaca berbagai informasi dapat diserap sehingga pengetahuan, pengalaman dan wawasan yang dimiliki akan semakin luas. Farr (dalam Dalman, 2013:5) mengemukakan bahwa "reading is the heart of education" yang artinya bahwa membaca merupakan jantung pendidikan. Hal ini berarti, semakin sering membaca maka pendidikannya akan semakin maju. Namun, tidak semua orang menyadari akan pentingnya hal tersebut dan belum menjadikan kegiatan membaca sebagai kebutuhan.

Pada dasarnya, membaca tidak hanya sekadar mengenal lambang tulisan, mencari arti kata sulit dalam suatu teks bacaan, dan menyuarakan bunyi bahasa. Akan tetapi lebih dari itu, membaca melibatkan pemahaman terhadap apa yang dibacanya, apa maksudnya, dan apa implikasinya. Saddhono dan Slamet (2014:133) memberikan pengertian membaca pemahaman sebagai kegiatan membaca yang dilakukan dengan penuh penghayatan untuk menyerap apa yang seharusnya dikuasai siswa atau pembaca. Kemampuan siswa dalam memahami suatu bacaan akan berpengaruh terhadap prestasi yang dimiliki siswa. Somadayo (2013) menyatakan bahwa siswa yang memiliki kemampuan membaca pemahaman kurang, akan mengalami kesulitan bahkan gagal dalam pembelajaran. Begitu sebaliknya, siswa yang memiliki kemampuan membaca pemahaman baik, tentunya akan lebih mudah untuk berhasil dalam pembelajaran.

Penelitian yang dilakukan Warsono (dalam Somadayo, 2011:3) tentang profil kemampuan membaca pemahaman siswa Sekolah Dasar di Jawa Tengah menunjukkan bahwa secara keseluruhan hasil skor membaca pemahaman siswa masuk dalam kategori yang relatif rendah. Studi lain tentang kemampuan membaca oleh The International Association for Evaluation (IEA) melalui tes Progress in International Reading Literacy Study (PIRLS) tahun 2011, mengungkapkan bahwa kemampuan membaca siswa SD/MI di Indonesia tergolong rendah. Berdasarkan hasil penelitian tersebut, hanya 5\% siswa Indonesia yang memiliki kemampuan membaca sampai pada tingkat high dan advance, lebih dari $30 \%$ pada tingkat very low, hampir $40 \%$ hanya pada tingkat low, dan hanya $25 \%$ saja yang mencapai tingkat intermediate (dalam Surnyaman,2015).

Menurut Rahim (2008:17), salah satu faktor yang mempengaruhi kemampuan membaca pemahaman siswa adalah metode yang digunakan guru dalam mengajar. Abidin (2013:153-154) menyatakan bahwa dalam mata pelajaran bahasa Indonesia, pembelajaran membaca masih dilaksanakan secara asal-asalan. Kegiatan membaca yang dilaksanakan di sekolah tidak pernah disertai dengan strategi membaca yang dapat digunakan untuk mendekati wacana tersebut. Hal inilah yang menyebabkan ratarata siswa hanya mampu membaca secara monoton dan tidak pernah tahu cara praktis dalam memahami bacaan karena menerapkan gaya membaca yang sama untuk setiap bahan bacaan.

Berdasarkan hasil wawancara yang dilakukan dengan guru kelas V dibeberapa SD Negeri Kecamatan Laweyan Kota Surakarta menunjukkan bahwa dalam pembelajaran membaca pemahaman, guru belum menerapkan strategi pembelajaran yang tepat. Kegiatan yang sering dilakukan yaitu guru menugaskan siswa untuk membaca secara bergiliran dengan teknik bersuara. Hal ini bertentangan dengan prinsip membaca pemahaman, yaitu membaca dalam hati.

Pemahaman terhadap suatu bacaan merupakan suatu proses yang bergulir terus menerus dan berkelanjutan sehingga guru perlu memberikan perhatian lebih terhadap pembelajaran membaca. Hal yang dapat dilakukan yaitu menerapkan strategi pembelajaran yang tepat bagi siswa. Salah satu strategi pembelajaran yang dapat 
digunakan yaitu strategi pembelajaran Directed Reading Thinking Activity (DRTA). Menurut Susanto (2016:91), strategi pembelajaran Directed Reading Thinking Activity (DRTA) adalah strategi yang paling efektif digunakan untuk pembelajaran membaca pemahaman di Sekolah Dasar yaitu. Strategi tersebut menekankan pada pengembangan proses berpikir tinggi. Selain itu, dapat melibatkan pemahaman secara aktif dan pertukaran gagasan diantara siswa serta efektif dalam mengarahkan dinamika sosial yang terjadi dalam kelompok. Pernyataan tersebut juga didukung oleh Katherine A. Doughter (2008:10) yang memperoleh simpulan pada penelitiannya bahwa strategi Directed Reading Thinking Activity (DRTA) merupakan strategi pembelajaran yang sangat efektif dibandingkan dengan strategi pembelajaran lainnya. Strategi ini dapat meningkatkan daya ingat siswa dan menghasilkan statistik efek yang signifikan dalam kemampuan membaca pemahaman.

Penelitian yang dilakukan oleh Kusuma (2014) menunjukkan bahwa strategi Directed Reading Thinking Activity (DRTA) berpengaruh positif terhadap keterampilan membaca pemahaman siswa kelas $\mathrm{V}$ SD dibandingkan dengan strategi pembelajaran konvensional. Hal senada juga terdapat pada peneltian Lestari (2015) yang memperoleh simpulan bahwa penggunaan strategi Directed Reading Thinking Activity (DRTA) dengan media gambar dapat meningkatkan keterampilan membaca pemahaman siswa kelas V SD. Dua hasil penelitian tersebut membuktikan bahwa strategi pembelajaran Directed Reading Thinking Activity (DRTA) berpengaruh terhadap kemampuan membaca pemahaman.

Strategi pembelajaran lain yang dapat digunakan terkait materi membaca pemahaman adalah strategi pembelajaran Know-Want to Know-Learned (KWL). Strategi tersebut merupakan strategi yang dapat membantu guru untuk menghidupkan latar belakang pengetahuan dan minat siswa pada suatu topik (Rahim,2008:41). Ada tiga langkah dasar yang terdapat pada strategi pembelajaran Know-Want to KnowLearned (KWL) yang menuntun siswa memberikan jalan tentang apa yang telah mereka ketahui, menentukan apa yang ingin mereka ketahui, dan mengingat kembali apa yang mereka pelajari dari membaca.

Penelitian yang dilakukan oleh Nurcahyanti (2017) menunjukkan bahwa penerapan strategi Know-Want to Know-Learned (KWL) dapat meningkatkan kemampuan membaca pemahaman siswa kelas V SD. Hal sama juga terdapat pada penelitian Astiti (2014) yang memperoleh simpulan bahwa penerapan strategi pembelajaran Know-Want to Know-Learned (KWL) melalui cerita rakyat memberikan pengaruh signifikan terhadap materi membaca bahasa Indonesia kelas $\mathrm{V} S \mathrm{SD}$. Dua hasil penelitian tersebut membuktikan bahwa strategi pembelajaran Know-Want to Know-Learned (KWL) berpengaruh terhadap kemampuan membaca pemahaman siswa.

Selain strategi pembelajaran, minat membaca juga berpengaruh terhadap kemampuan membaca pemahaman siswa. Berdasarkan data dari United Nations Educational, Scientific, and Cultural Organization (UNESCO) persentase minat membaca anak Indonesia hanya 0,01 persen. Hal ini menunjukkan dari 1000 anak, hanya ada satu anak yang gemar membaca. Rendahnya minat membaca juga telah dibuktikan oleh studi "Most Littered Nation In the World" yang dilakukan oleh Central Connecticut State Univesity. Hasil survei pada tahun 2016 soal minat membaca, Indonesia menduduki peringkat ke-60 dari 61 negara, yaitu di bawah Thailand dan di atas Bostwana (Kompas, 7 februari 2017).

Herlinyanto (2015) menyatakan bahwa seorang pemmembaca perlu memiliki minat yang kuat dalam memahami sebuah teks membacaan. Minat merupakan kekuatan penting yang dapat mendorong pemmembaca untuk memperhatikan, tertarik, dan senang terhadap aktivitas membaca sehingga dapat membangun kepribadian dan kemampuan inteleknya. Fitriana (dalam Muslim, 2017) pada penelitiannya memperoleh simpulan bahwa ada hubungan yang positif dan signifikan antara minat membaca 
dengan kemampuan memahami membacaan. Semakin tinggi minat membaca siswa, maka semakin tinggi pula kemampuannya dalam memahami membacaan. Begitu sebaliknya, semakin rendah minat membaca siswa, maka semakin rendah pula kemampuannya dalam memahami membacaan.

Kategori minat membaca yang dimiliki setiap siswa pasti berbeda antara satu dengan yang lainnya. Begitu pun dalam proses membaca pemahaman, ada yang kategori minat membacanya tinggi dan ada pula yang kategori minat membacanya rendah. Mengetahui perbedaan kategori minat membaca siswa dapat membantu guru untuk membimbing siswa dalam mengkonstruksi pemahamannya terhadap suatu membacaan. Selain itu, dapat dijadikan bahan pertimbangan dalam memilih strategi pembelajaran yang tepat untuk diterapkan dalam kegiatan pembelajaran sehingga kemampuan membaca pemahaman siswa menjadi lebih baik.

Berdasarkan uraian latar belakang di atas, maka rumusan masalah dalam penelitian ini adalah: (1) apakah ada perbedaan kemampuan membaca pemahaman antara siswa yang diajar dengan menggunakan strategi pembelajaran Directed Reading Thinking (DRTA)dan strategi pembelajaran Know-Want to Know-Learned (KWL)?. Jika ada perbedaan, manakah yang lebih baik?; (2) apakah ada perbedaan signifikan antara siswa yang mempunyai minat membaca tinggi dan minat membaca rendah terhadap kemampuan membaca pemahaman?. Jika ada perbedaan manakah yang lebih baik?; dan (3) apakah ada interaksi antara strategi pembelajaran dan minat membaca terhadap kemampuan membaca pemahaman siswa?

Adapun tujuan penelitian ini adalah: (1) mengetahui perbedaan kemampuan membaca pemahaman antara siswa yang diajar dengan menggunakan strategi pembelajaran Directed Reading Thinking (DRTA) dan strategi pembelajaran KnowWant to Know-Learned (KWL); (2) mengetahui perbedaan kemampuan membaca pemahaman antara siswa yang mempunyai minat membaca tinggi dan minat membaca rendah; dan (3) mengetahui interaksi antara strategi pembelajaran dan minat membaca terhadap kemampuan membaca pemahaman siswa.

Penelitian ini merupakan penelitian kuantitatif menggunakan metode eksperimental semu (quasi eksperimetal) dengan desain penelitian randomized pretest-posttest control group design. Populasi penelitian ini adalah seluruh siswa kelas V SD Negeri Se-Kecamatan Laweyan Surakarta Tahun Ajaran 2017/2018. Teknik pengambilan sampel yang digunakan adalah cluster random sampling. Sampel penelitian ini yaitu SD Negeri Pajang 1 sebagai kelompok eksperimen dan SD Negeri Karangasem 1 sebagai kelompok kontrol. Teknik pengumpulan data yang digunakan yaitu teknik tes untuk memperoleh data tentang kemampuan membaca pemahaman siswa dan teknik non tes untuk memperoleh data tentang minat membaca siswa. Uji prasyarat analisis menggunakan uji normalitas dengan uji Liliefors, uji homogenitas dengan uji Bartlett, dan uji keseimbangan dengan uji-t tipe Polled Varians. Teknik analisis data yang digunakan adalah analisis variansi dua jalan dengan sel tak sama dan uji lanjut pasca anava dengan uji Scheffe untuk mengetahui pengaruh variabel yang lebih baik.

\section{HASIL DAN PEMBAHASAN}

Sebelum uji analisis data terlebih dahulu dilakukan uji prasyarat analisis yaitu uji menggunakan uji normalitas, uji homogenitas, dan uji keseimbangan kemampuan awal antara kelompok eksperimen dan kelompok kontrol. 
Tabel 1. Rataan dan Variansi Data Pretest

\begin{tabular}{lccc}
\hline Kelompok & $\begin{array}{c}\text { Jumlah } \\
\text { Siswa }\end{array}$ & $\mathrm{X}$ & $\mathrm{S}$ \\
\hline Eksperimen & 43 & 58,546 & 16,431 \\
Kontrol & 42 & 60,892 & 13,409 \\
\hline
\end{tabular}

Berdasarkan Tabel 1, dapat diketahui bahwa pada kelompok eksperimen diperoleh rata-rata skor 58,546 dengan standar deviasi sebesar 11,431. Adapun pada kelompok kontrol diperoleh rata-rata skor 60,892 dengan standar deviasi sebesar 13,409 .

\begin{tabular}{|c|c|c|c|}
\hline Sampel & $L_{\text {hitung }}$ & $\mathrm{L}_{\text {tabel }}$ & $\begin{array}{c}\text { Keputusan } \\
\text { Uji }\end{array}$ \\
\hline $\begin{array}{c}\text { Eksperimen } \\
\text { Kontrol }\end{array}$ & $\begin{array}{l}0,092 \\
0.129\end{array}$ & $\begin{array}{l}0,135 \\
0,136\end{array}$ & $\mathrm{H}_{0}$ diterima \\
\hline
\end{tabular}

Berdasarkan Tabel 2, dapat diketahui bahwa pada masing-masing sampel penelitian harga $L_{\text {hitung }}$ tidak melebihi harga $L_{\text {tabel }}$ sehingga $H_{0}$ diterima yang berarti bahwa kedua sampel berasal dari populasi yang berdistribusi normal.

Hasil uji homogenitas dengan uji Bartlett menggunakan stasistik uji Chi-Kuadrat pada tingkat signifikan 0,05 diperoleh hasil bahwa nilai uji statistik dari kelompok eksperimen dan kelompok kontrol adalah $X^{2}$ hitung $=1,699$ dan $X_{\text {tabel }}^{2}=3,841$ atau $X^{2}$ hitung= $1,699<X^{2}$ tabel $=3,841$ maka $H_{0}$ diterima. Hal ini berarti kedua kelompok homogen.

Sampel penelitian berasal dari populasi yang berdistribusi normal dan variansinya homogen. Selanjutnya dilakukan uji keseimbangan menggunakan statistik uji-t dengan rumus $t$-test Polled Varians karena jumlah siswa $(n)$ pada kedua kelompok berbeda. Hasil uji keseimbangan diperoleh $t_{\text {hitung }}=-0,048 \notin D K=\{t \mid t<1,989$ atau $t>$ $1,989\}$ atau $t_{\text {hitung }}$ bukan anggota daerah kritis, maka $H_{0}$ diterima. Hal ini berarti kemampuan awal kedua sampel tersebut dalam keadaan seimbang atau kedua sampel penelitian memiliki kemampuan awal yang sama.

Tabel 3. Hasil Uji Normalitas

\begin{tabular}{llll}
\multicolumn{1}{c}{ Kelompok } & $\mathbf{L}_{\text {hitung }}$ & $\mathbf{L}_{\text {tabel }}$ & \multicolumn{1}{c}{ Keputusan Uji } \\
\hline Eksperimen & 0,108 & 0,135 & Ho diterima atau sampel \\
Kontrol & 0,064 & 0,136 & berasal dari populasi \\
$\begin{array}{l}\text { Minat Membaca } \\
\text { Tinggi }\end{array}$ & 0,077 & 0,135 & yang berdistribusi normal \\
$\begin{array}{l}\text { Minat Membaca } \\
\text { Rendah }\end{array}$ & 0,086 & 0,136 & \\
\hline
\end{tabular}

Berdasarkan Tabel 3, dapat diketahui bahwa harga $L=\left\{\left|F\left(z_{i}\right)-S\left(z_{i}\right)\right|\right\}$ di atas, hasil $L_{\text {hitung }}$ tidak melebihi harga $L_{\text {tabel }}$ sehingga $H_{0}$ diterima. Hal ini berarti sampel penelitian berasal dari populasi yang berdistribusi normal.

Tabel 4. Hasil Uji Homogenitas

\begin{tabular}{lccc}
\hline \multicolumn{1}{c}{ Sumber } & $\chi_{\text {hitung }}^{2}$ & $\chi_{\text {tabel }}^{2}$ & Keputusan Uji \\
\hline $\begin{array}{l}\text { Kelompok Eksperimen dan } \\
\text { Kontrol }\end{array}$ & 1,979 & 3,841 & $\mathrm{H}_{0}$ diterima \\
$\begin{array}{l}\text { Kelompok Minat Membaca } \\
\text { Tinggi dan Rendah }\end{array}$ & 1,043 & 3,481 & $\mathrm{H}_{0}$ diterima \\
Antar Sel & 5,697 & 7,815 & $\mathrm{H}_{0}$ diterima \\
\hline
\end{tabular}


Berdasarkan Tabel 4, dapat diketahui bahwa $x^{2}$ hitung pada kelompok eksperimen dan kelompok kontrol, minat membaca tinggi dan minat membaca rendah, serta antar sel tidak melebihi harga $\mathrm{X}_{\text {tabel }}^{2}$ sehingga $\mathrm{H}_{0}$ diterima. Hal ini berarti ketiga kelompok memiliki varians yang sama atau homogen.

Uji Hipotesis menggunakan analisis variansi dua jalan dengan sel tak sama pada taraf signifikan 0,05 . Hasil perhitungan analisis variansi dua jalan dengan sel tak sama dapat dilihat pada Tabel 5 sebagai berikut:

Tabel 5. Hasil Analisis Variansi Dua Jalan dengan Sel Tak Sama

\begin{tabular}{ccccccc}
\hline $\begin{array}{c}\text { Sumber } \\
\text { Varians }\end{array}$ & JK & $\mathbf{1}$ & RJK & $\mathbf{F}_{\text {hitung }}$ & $\mathbf{F}_{\text {tabel }}$ & $\begin{array}{c}\text { Keputusan } \\
\text { Uji }\end{array}$ \\
\hline Antar A & 1608,763 & 1 & 1608,763 & 25,669 & 3,11 & $\mathrm{H}_{0 \mathrm{AA}}$ ditolak \\
Antar B & 3686,822 & 1 & 3686,822 & 58,827 & 3,11 & $\mathrm{H}_{\text {OB }}$ ditolak \\
Antar AxB & 448,266 & 1 & 448,266 & 7,790 & 3,11 & $\mathrm{H}_{0 \mathrm{AXB}}$ ditolak \\
Dalam & 5076,4407 & 81 & 62,672 & - & - & - \\
Total & 10820,2941 & 84 & - & - & - & - \\
\hline
\end{tabular}

Berdasarkan Tabel 5, dapat disimpulkan bahwa: (1) Ada perbedaan kemampuan membaca pemahaman antara siswa yang diajar dengan strategi pembelajaran Directed Reading Thinking Activity (DRTA) dan siswa yang diajar dengan strategi pembelajaran Know-Want to Know-Learned (KWL) dengan nilai $F_{A}=25,669>$ $\mathrm{F}_{(0,05 ; 2,82)}=3,11$; (2) Ada perbedaan kemampuan membaca pemahaman antara siswa yang memiliki minat membaca tinggi dan siswa yang memiliki minat membaca rendah dengan nilai $F_{B}=58,827>F_{(0,05 ; 2,82)}=3,11$; dan (3) Ada interaksi antara strategi pembelajaran dan minat membaca terhadap kemampuan membaca pemahaman siswa dengan nilai $F_{A B}=7,790>F_{(0,05 ; 2,820)}=3,11$. Berdasarkan hasil perhitungan analisis variansi dua jalan dengan dengan sel tak sama, pada koefisien $F_{A}, F_{B}$, dan $F_{A B}$ menunjukkan bahwa ada perbedaan yang signifikan, sehingga perlu dilakukan uji lanjut pasca Anava menggunakan uji Scheffe untuk mengetahui pengaruh variabel manakah yang lebih baik. Pada hipotesis pertama $\left(\mathrm{H}_{\mathrm{OA}}\right.$ dan hipotesis kedua $\left(\mathrm{H}_{0 \mathrm{~B})}\right.$ tidak perlu dilakukan uji lanjut pasca anava karena mempunyai dua kategori. Untuk mengetahui hasil yang lebih baik, hanya perlu membandingkan jumlah rataan marginalnya. Hasil rataan skor tersebut dapat dilihat pada Tabel 6 sebagai berikut:

Tabel 6. Rataan Skor Masing-masing Sel

\begin{tabular}{cccc}
\hline \multirow{2}{*}{ Strategi Pembelajaran } & \multicolumn{2}{c}{ Minat Membaca } & Rataan \\
& Tinggi $\left(\mathrm{B}_{1}\right)$ & Rendah $\left(\mathrm{B}_{2}\right)$ & Marginal \\
\hline $\begin{array}{c}\text { Directed Reading } \\
\text { Thinking Activity (DRTA) }\end{array}$ & 82,142 & 71,426 & 76,784 \\
Know-Want to Know- & 75,833 & 59,375 & 67,604 \\
$\quad$ Learned (KWL) & 78,9875 & 65,4005 & - \\
Rataan Marginal & & & \\
\hline
\end{tabular}

Berdasarkan Tabel 6, dapat diketahui bahwa rataan marginal pada strategi pembelajaran Directed Reading Thinking Activity (DRTA) lebih tinggi daripada rataan marginal strategi pembelajaran Know-Want to Know-Learned (KWL), yaitu rataan marginal $A_{1}=76,784>$ rataan marginal $A_{2}=67,604$. Hal ini berarti siswa yang diajar dengan strategi pembelajaran Directed Reading Thinking Activity (DRTA) memiliki kemampuan membaca pemahaman yang lebih baik daripada siswa yang diajar dengan strategi pembelajaran Know-Want to Know-Learned (KWL). Adapun rataan marginal pada minat membaca tinggi lebih tinggi daripada rataan marginal minat membaca rendah, yaitu rataan marginal $B_{1}=78,9875>$ rataan marginal $B_{2}=65,4005$. 
Hal ini berarti siswa yang memiliki minat membaca tinggi memiliki kemampuan membaca yang lebih baik daripada siswa memiliki minat membaca rendah.

Selanjutnya, untuk hipotesis ketiga $\left(\mathrm{H}_{\mathrm{OAB}}\right)$, perlu dilakukan uji lanjut pasca anava (uji komparasi ganda) antar sel pada baris atau kolom yang sama. Hasil komparasi ganda antar sel baik pada baris yang sama ataupun pada kolom yang sama dapat dilihat pada Tabel 7 sebagai berikut:

Tabel 7. Hasil Uji Komparasi Ganda Antar Sel

\begin{tabular}{cccc}
\hline Komparasi & $\mathbf{F}_{\text {hitung }}$ & $\mathbf{F}_{\text {tabel }}$ & Keputusan Uji \\
\hline$A_{1} B_{1}-A_{2} B_{1}$ & 6,904 & 3,054 & $H_{0}$ ditolak \\
$A_{1} B_{2}-A_{2} B_{2}$ & 24,395 & 3,054 & $H_{0}$ ditolak \\
$A_{1} B_{1}-A_{1} B_{2}$ & 19,918 & 3,054 & $H_{0}$ ditolak \\
$A_{2} B_{1}-A_{2} B_{2}$ & 45,500 & 3,054 & $H_{0}$ ditolak \\
\hline
\end{tabular}

Berdasarkan Tabel 7 di atas dapat disimpulkan bahwa: (1) komparasi rataan antar sel $\left(A_{1} B_{1}-A_{2} B_{1}\right), H_{0}$ ditolak. Hal ini berarti siswa yang diajar dengan strategi pembelajaran Directed Reading Thinking Activity (DRTA) dan minat membacanya tinggi memiliki kemampuan membaca pemahaman yang lebih baik daripada siswa yang diajar dengan strategi pembelajaran Know-Want to Know-Learned (KWL) dan minat membacanya tinggi; (2) Komparasi rataan antar sel $\left(A_{1} B_{2}-A_{2} B_{2}\right), H_{0}$ ditolak. Hal ini berarti siswa yang diajar dengan strategi pembelajaran Directed Reading Thinking Activity (DRTA) dan minat membacanya rendah memiliki kemampuan membaca pemahaman yang lebih baik daripada siswa yang diajar dengan strategi pembelajaran Know-Want to Know-Learned (KWL) dan minat membacanya rendah; (3) komparasi rataan antar sel $\left(A_{1} B_{1}-A_{1} B_{2}\right), H_{0}$ ditolak. Hal ini berarti siswa yang diajar dengan strategi pembelajaran Directed Reading Thinking Activity (DRTA) dan minat membacanya tinggi memiliki kemampuan membaca pemahaman yang lebih baik daripada siswa yang diajar dengan strategi pembelajaran Directed Reading Thinking Activity (DRTA) dan minat membacanya rendah; dan (4) komparasi rataan antar sel $\left(\mathrm{A}_{2} \mathrm{~B}_{1}-\mathrm{A}_{2} \mathrm{~B}_{2}\right) \mathrm{H}_{0}$ ditolak. Hal ini berarti siswa yang diajar dengan strategi pembelajaran Know-Want to Know-Learned (KWL) dan minat membacanya tinggi memiliki kemampuan membaca pemahaman yang lebih baik daripada siswa yang diajar dengan strategi pembelajaran Know-Want to Know-Learned (KWL) dan minat membacanya rendah.

\section{SIMPULAN}

Simpulan yang dapat ditarik pada penelitian ini antara lain: (1) Ada perbedaan kemampuan membaca pemahaman antara siswa yang diajar dengan strategi pembelajaran Directed Reading Thinking Activity (DRTA) dan siswa yang diajar dengan strategi pembelajaran Know-Want to Know-Learned (KWL); (2) Ada perbedaan kemampuan membaca pemahaman antara siswa yang memiliki minat membaca tinggi dan siswa yang memiliki minat membaca rendah; (3) Ada interaksi antara strategi pembelajaran dan minat membaca terhadap kemampuan membaca pemahaman.

Saran yang dapat menjadi bahan pertimbangan yaitu: (1) Siswa hendaknya aktif dan antusias dalam mengikuti pelajaran, berani dalam mengemukakan pendapat, dan menghargai pendapat oranglain saat diskusi; (2) Guru hendaknya mau menerapkan strategi pembelajaran yang tepat dan dapat mendorong keaktifan siswa dalam kegiatan belajar mengajar sehingga tercipta suasana belajar mengajar yang efektif dan efisien. Salah satu strategi pembelajaran yang dapat digunakan guru dalam pembelajaran terkait materi membaca pemahaman adalah strategi pembelajaran Directed Reading Thinking Activity (DRTA); (3) Sekolah hendaknya mengadakan pelatihan untuk guru agar dapat menerapkan strategi pembelajaran yang inovatif; dan (4) Peneliti yang akan datang dapat menjadikan penelitian ini sebagai bahan rujukan 
dan menyempurnakan hasil penelitian ini dengan mengadakan penelitian yang menerapkan strategi pembelajaran Directed Reading Thinking Activity (DRTA).

\section{DAFTAR PUSTAKA}

Abidin, Yunus. (2013). Pembelajaran Bahasa Berbasis Pendidikan Karakter. Bandung: PT Refika Aditama.

AR, Muslim. (2017). Pengaruh Minat Membaca Terhadap Prestasi Belajar Siswa Sekolah. Prosiding TEP \& PDs. 1(10), 56-63.

Astiti, Kadek Jati. (2014). Pengaruh Strategi Know-Want to Know-Learned (KWL) Terhadap Membaca Bahasa Indonesia Siswa Kelas V SD Gugus VII Sukawati. eJournal MIMBAR PGSD Universitas Pendidikan Ganesha, 2(1), 1-10.

Dalman. (2013). Keterampilan Membaca. Jakarta: Rajawali Press.

Herliyanto. (2015). Membaca Pemahaman dengan Strategi KWL. Yogyakarta: CV. Budi Utama.

Kusuma, Ida Bagus Indra. (2014). Pengaruh Strategi Directed Reading Thingking Activity (DRTA) Terhdap Keterampilan Membaca Pemahaman Siswa. e-Journal MIMBAR PGSD Universitas Pendidikan Ganesha. 2(1). 1-10.

Lestari, Nenik. (2014). Penggunaan Strategi Directed Reading Thinking Activity (DRTA) dengan Media Gambar Dalam Meningkatkan Keterampilan Membaca Pemahaman di Kelas $V$ SDN 5 Kebumen Tahun Ajaran 2014/2015. Surakarta: Universitas Sebelas Maret.

Nurcahyati, Beta. (2017). Peningkatan Keterampilan Membaca Pemahaman Melalui Metode Know-Want to Konow-Learned (KWL) pada Siswa Kelas V SD Negeri 1 Kertosari Temanggung. Yogyakarta: Universitas Negeri Yogyakarta.

Rahim, Farida. (2008). Pengajaran Membaca di Sekolah Dasar.Jakarta: Bumi Aksara.

Somadayo, Samsu. (2011). Strategi dan Teknik Pembelajaran Membaca. Yogyakarta: Graha IImu.

Somadayo, Samsu. (2013). The Effect of Learning Model DRTA (Directed Reading Thingking Activity) Toward Students' Reading Comprehension Ability Seeing from Their Reading Interest. Journal of Education and Practice. 4(8),115-112.

Saddhono, Kundharu dan St.Y.Slamet. (2014). Pembelajaran Keterampilan Berbahasa Indonesia. Yogyakarta: Graha IImu.

Suryaman, Maman. (2015). Analisis hasil Belajar Peserta Didik Dalam Literasi membaca Melalui Studi Internasional (PIRLS) 2011. LITERA. 14(1), 171-172. 